\title{
Short Communication: \\ DNA barcodes and phylogenetic of striped snakehead and ocellated snakehead fish from South Sumatra, Indonesia
}

\author{
MOCHAMAD SYAIFUDIN, MARINI WIJAYANTI, SEFTI HEZA DWINANTI, MUSLIM, \\ MUHAMMAD MAHENDRA, SHELY MARLIANA \\ Program of Aquaculture, Faculty of Agriculture, Universitas Sriwijaya. Jl. Raya Palembang-Prabumulih Km 32, Indralaya, Ogan Ilir 30662, South \\ Sumatra, Indonesia. Tel.: +62-711-580663, Fax.: +62-711-580276, ^email: msyaifudin@fp.unsri.ac.id
}

Manuscript received: 4 December 2019. Revision accepted: 25 February 2020

\begin{abstract}
Syaifudin M, Wijayanti M, Dwinanti SH, Muslim, Mahendra M, Marliana S. 2020. DNA barcodes and phylogenetic of striped snakehead and ocellated snakehead fish from South Sumatra, Indonesia. Biodiversitas 21: 1227-1235. This research aimed to identify the sequences of cytochrome c oxidase subunit I gene mitochondrial DNA (COI mtDNA), to construct a phylogenetic tree of striped snakehead (Channa striata) and ocellated snakehead (Channa pleuropthalma), and to measure water quality of Kelekar River, Indralaya, Ogan Ilir District and Danau Burung Besar River, Penukal Abab Lematang Ilir (PALI) District in South Sumatra, Indonesia. The research procedures consisted of DNA isolation, amplification by PCR (Polymerase Chain Reaction) and sequencing of fragment COI mtDNA. The length of nucleotide was $604 \mathrm{bp}$ for striped snakehead and 587-604 bp for ocellated snakehead. Optimum annealing temperature was $50^{\circ} \mathrm{C}$ for 15 seconds with 30 cycles. The result of BLAST analysis showed that striped snakehead from Kelekar and Danau Burung Besar River had 100\% identity to striped snakehead from Java-Bali and furthest (97\%) with striped snakehead from India. Ocellated snakehead had 100\% similarity with the same species from Musi Banyuasin and Banjarmasin; and furthest (83\%) with Channa limbata from Myanmar. Water quality in Kelekar River were temperature 31-31.6 ${ }^{\circ} \mathrm{C}$, pH 4.76-4.96, dissolved oxygen 2.7-3.0 $\mathrm{mg} / \mathrm{L}$, ammonia $<0.009 \mathrm{mg} / \mathrm{L}$, total alkalinity $20 \mathrm{mg} / \mathrm{L}$, and turbidity $62.5-63 \mathrm{~cm}$. Meanwhile in Danau Burung Besar River showed temperature $\left(29.3-30.7^{\circ} \mathrm{C}\right), \mathrm{pH}(3.6-6.7)$, dissolved oxygen $(1.31-3.76 \mathrm{mg} / \mathrm{L})$, ammonia $(0.17-0.20 \mathrm{mg} / \mathrm{L})$, and turbidity $(50-90 \mathrm{~cm})$.
\end{abstract}

Keywords: COI, ocellated snakehead, phylogenetics, striped snakehead

\section{INTRODUCTION}

Striped snakehead (Channa striata) is economically important fish in Sumatra, Indonesia. There are some popular foods made from this fish, for instance, pempek, model, tekwan and cracker. Recently, domestication and artificial breeding of this fish have already been done, however genetic authentication of this fish is still limited in Indonesia. Growing this fish is also not successful until commercial size. Furthermore, decreasing water quality due to land use change, pollution and overfishing lead to decreasing in fish production in the wild. Therefore, fish genetic research, reproduction, and habitat characteristics in the wild are beneficial for initial attempt in aquaculture. Channidae has 2 genera i.e Channa and Parachanna. Channa is originally from Asia, while Parachanna is native to Africa. All these fish in this family are known as snakeheads (Courtenay and Williams 2004). There are four species of Channa in Kelekar River (Indralaya sub-district, Ogan Ilir District) i.e toman (Channa micropeltes), serandang (Channa pleuropthalma), gabus (Channa striata), and bujuk (Channa lucius) (Muslim, 2013). Ocellated snakehead, a native species in Musi River, Batanghari and Barito, has economic value for consumption in Sumatra and Kalimantan (Kotellat et al. 1993).

There are 37 species in family Channidae globally, which consisted of 34 species are Channa (Asia) and three species are Parachanna (Africa) (Froese and Pauly, 2018). Therefore, robust identification for species is important, especially for comparison between wild and cultured population dan rehabilitation program (Rajiv and Chauhan, 2010). Mitochondrial DNA can be used to investigate evolutionary process with high resolution (Brown et al. 1979). Sequencing of this region has been widely used to discriminate species level (Nagl et al. 2001) and population study (Rognon and Guyomard 1997; D'Amato et al. 2007). Cytochrome C Oxidase subunit I is one of mtDNA genes, which is conserved, used for distinguishing species and population.

The COI gene is one of the molecular markers used to identify a species (Ward et al. 2005) that has conservative nucleotide base sequences and has little variation deletion, and insertion (Hebert et al. 2003). This technology (DNA barcoding) relies on the observation that the 'barcode' sequence divergence within species is typically much lower than the divergence exhibited between species (Hebert et al. 2003). This technique has been widely used for barcoding DNA for shark (Peloa et al. 2015), baung Hemibagrus nemurus (Syaifudin et al. 2017), Pangasius Pangasius hypophthalmus (Pratama et al. 2017), wild stock and the first generation (F1) of Channa spp. (Irmawati et al. 2017), tilapia (Syaifudin et al. 2019), snakeskin gourami and blue gourami (Syaifudin et al. 2019). This research aimed to obtain nucleotide sequences of COI gene of $C$. 
striata and $C$. plurophthalma, construct a phylogenetic tree and characterize water quality of fish habitat in the Kelekar and Danau Burung Besar River in South Sumatra.

\section{MATERIALS AND METHODS}

\section{Biological materials}

Four individuals each species of striped snakehead and ocellated snakehead were collected from Kelekar River in Indralaya, Ogan Ilir District and Danau Burung Besar River, Penukal Abab Lematang Ilir (PALI) District at South Sumatra Provinces, Indonesia (Fig. 1). Fish were captured in the wild with the help of local fishermen in the research area. Approximately $3 \mathrm{~cm}$ of a segment of the caudal fin was snipped and preserved in 99\% ethanol $(1: 10$ $w: v)$, then stored in individual Eppendorf tubes at $-20^{\circ} \mathrm{C}$ until required.

\section{DNA extraction}

A total of 8 fin clips from two species have been used in genomic DNA extraction. Total genomic DNA was extracted based on Geneaid DNA Extraction kit (GT 100 Geneaid Biotech Ltd. Taiwan) as outlined in the manufacturer's protocol. An RNAse incubation step was included to minimize RNA contamination. DNA samples were further stored in freezer $\left(-20^{\circ} \mathrm{C}\right)$ until required. Those samples that showed no observable RNA and comprising predominantly high molecular weight DNA were selected for PCR (Polymerase Chain Reaction).

\section{DNA amplification}

In order to amplify $650 \mathrm{bp}$ fragment, the DNA of stripped snakehead and ocellated snakehead were used in PCR with primer pairs of FishF2-5, TCGACTAATCATAAAGATATCGGCAC 3' and FishR2-5' ACTTCAGGGTGACCGAAGAATCAGAA 3' (Ward et al. 2005). PCR was performed in $40 \mu \mathrm{l}$ final volumes using KAPA HiFi HotStart ReadyMixPCR kit (Kapa Biosystems, Massachusetts, United States). Each reaction contained $1.6 \mu \mathrm{l}$ of $10 \mu \mathrm{M}$ each primer, $14.8 \mu \mathrm{l}$ of nuclease-free water, $20 \mu \mathrm{l}$ of $2 \mathrm{x}$ KAPA HiFi HotStart ReadyMix and $2 \mu \mathrm{l}$ of DNA template. The thermal cycling protocol was as follows: initial denaturation at $95^{\circ} \mathrm{C}$ for 3 min followed by 30 cycles of $98^{\circ} \mathrm{C}$ for $20 \mathrm{sec}$, annealing at $50^{\circ} \mathrm{C}$ for $15 \mathrm{sec}$, extension at $72^{\circ} \mathrm{C}$ for $30 \mathrm{sec}$ and a final extension at $72^{\circ} \mathrm{C}$ for $1 \mathrm{~min}$. Optimation of PCR resulted in an annealing temperature of $50^{\circ} \mathrm{C}$ (temperature melting/Tm of primer is $54.5^{\circ} \mathrm{C}$ ). The temperature of annealing can be used in the range of $\left(\mathrm{Tm}-5^{\circ} \mathrm{C}\right)$ to $\left(\mathrm{Tm}+5^{\circ} \mathrm{C}\right)$. Amplified fragments were run in electrophoresis $1 \%$ agarose gel at 75 $\mathrm{V}$ for $40 \mathrm{~min}$ with $1 \mathrm{~Kb}$ marker and visualized using GelDoc. PCR products were described in Figure 2.

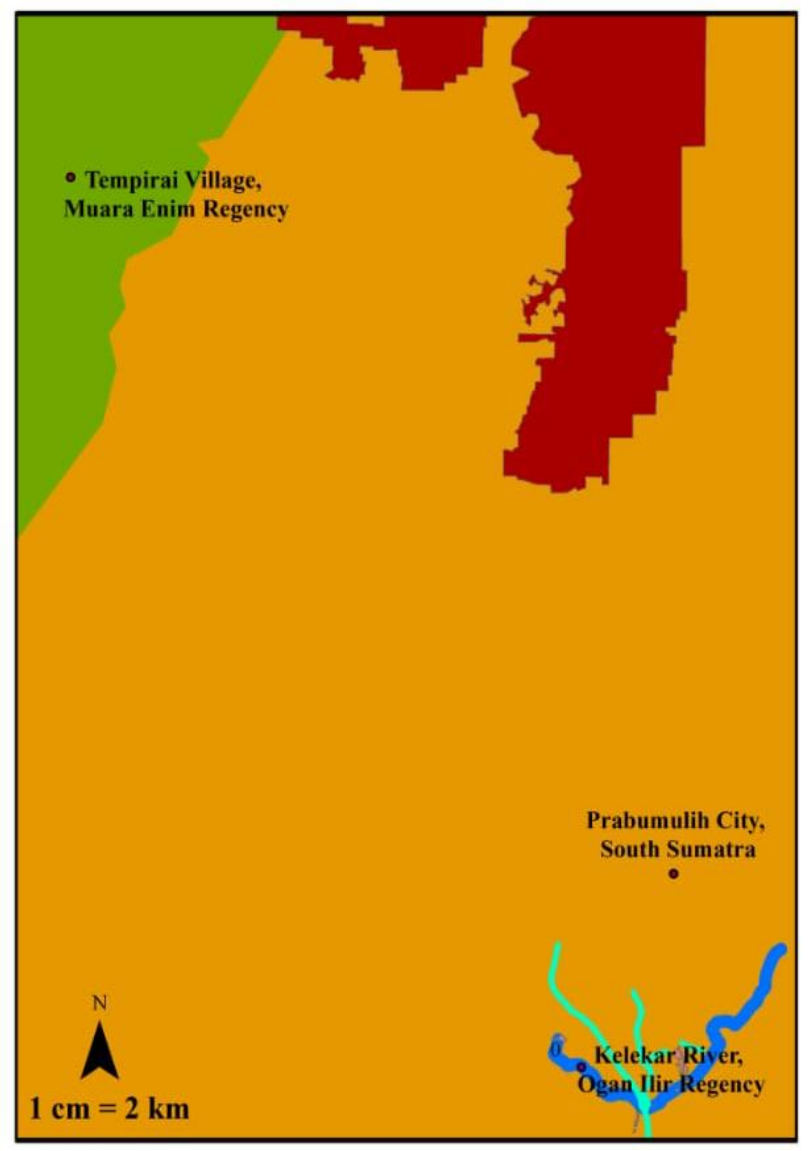

\section{RESEARCH MAP LOCATION}
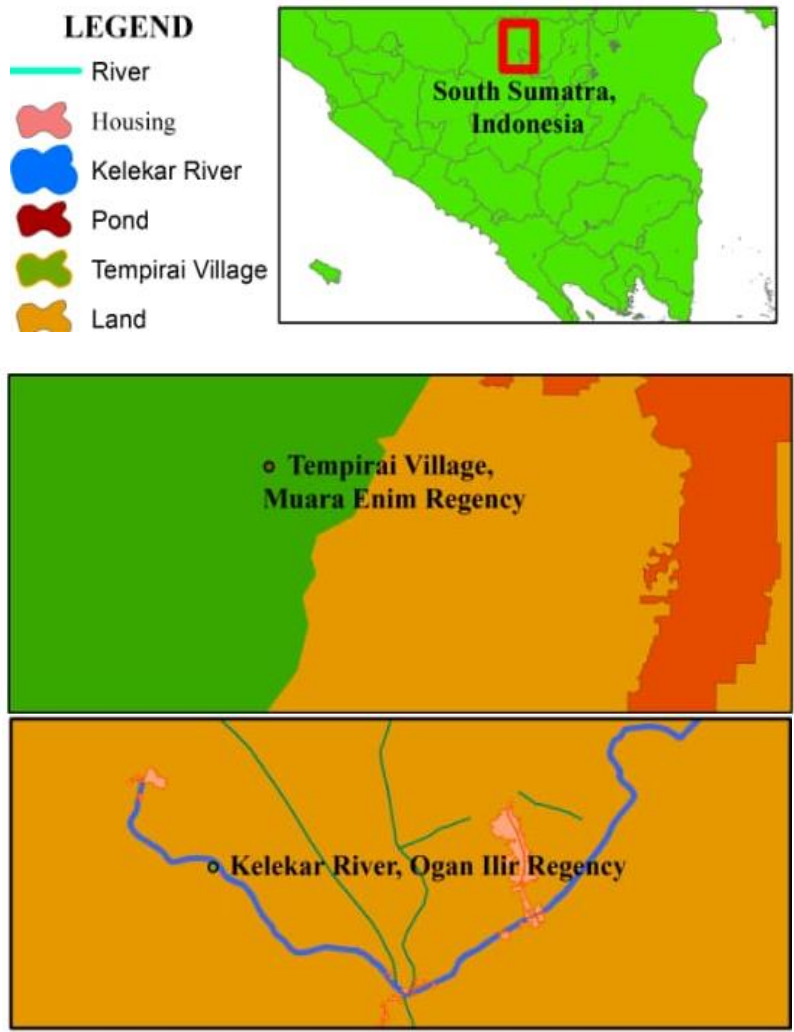

Figure 1. Sampling site of striped snakehead and ocellated snakehead collected from Kelekar River in Indralaya, Ogan Ilir District and Danau Burung Besar River, Penukal Abab Lematang Ilir (PALI) District at South Sumatra Provinces, Indonesia 


\section{COI gene sequencing}

Eight DNA samples derived from two species that were successfully amplified using PCR were then bi-direction sequenced at the target area of the COI gene in Singapore through the services of the Genetica Science Institute in Jakarta.

\section{Water quality}

The physical and chemical water qualities were characterized during sample collection in Kelekar and Danau Burung Besar River. The physical characteristics i.e turbidity $(\mathrm{cm})$ was measured using Secchi disc, while temperature $\left({ }^{\circ} \mathrm{C}\right)$ using a thermometer. The chemical water qualities i.e $\mathrm{pH}$ was measured using $\mathrm{pH}$ meter, dissolved oxygen (mg. $\mathrm{L}^{-1}$ ) using DO meter, ammonia (mg. $\left.\mathrm{L}^{-1}\right)$ using spectrophotometer and total alkalinity $\left(\mathrm{mg} . \mathrm{L}^{-1} \quad \mathrm{CaCO}_{3}\right)$ using titrimetric method.

\section{Data analysis}

Four COI sequences of each species in Fasta format were aligned using MEGA 7.0 software (Kumar et al. 2016) for timing process. It was then blasted using BLASTn (Basic Local Alignment Search Tool-nucleotide) in GenBank NCBI (National Center for Biotechnology Information) on the sequence database http://www.ncbi.nlm.nih.gov to compare the similarity of the COI gene between the Channidae to those in the GenBank database. Each sequence from each individual was put together in the alignment file from Mega7 software. The polymorphic were determined by aligning the sequence to know nucleotide variations within and between species. The nucleotide sequence was translated to the amino acid sequence using software from http://web.expasy.org/translate. The sequence data of this study (size 587-604 bp) have been reported to GenBank with accession number for C. striata (MN992966MN992969) and C. pleurophthalma (MN992962MN992965). For sequence comparisons, pairwise genetic distances were quantified based on the Kimura 2-parameter (K2P) distance model (Kimura et al. 1980) using MEGA, version 7.0 (Kumar et al. 2016). Voucher sequences from GenBank, and consensus sequences of each species generated from this study were compared and aligned using the CLUSTALW program. Furthermore, all sequences were used to analyze the phylogenetic tree. The phylogenetic tree between species of striped snakehead and ocellated snakehead was constructed using the NeighborJoining (NJ) method in the MEGA 7.0. Oreochromis niloticus was also used as species outgroup in the analysis.

\section{RESULTS AND DISCUSSION}

\section{Species identity and phylogenetics}

The analysis through BLASTn on the NCBI showed the percentage of identity with the other sequences in GenBank, which is presented in Tables 1 and 2.

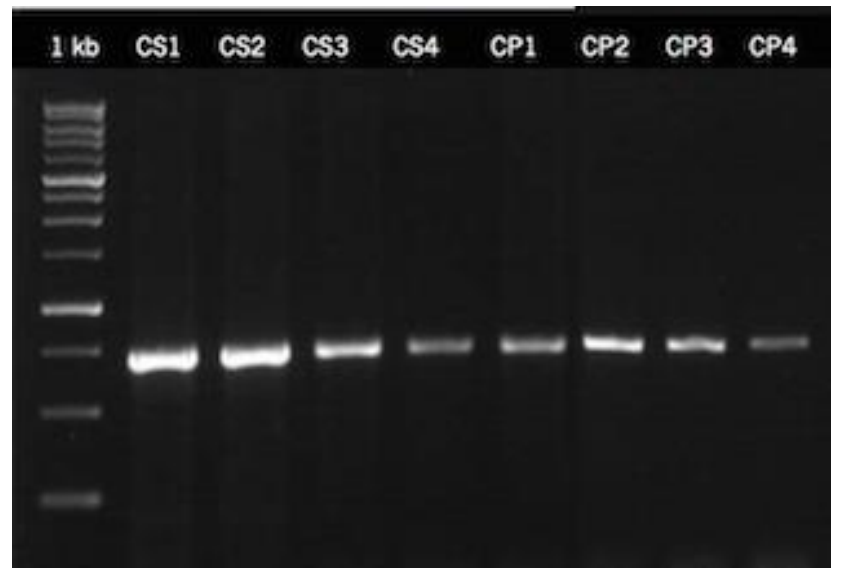

Figure 2. Visualization of PCR products of COI gene on stripped snakehead and ocellated snakehead. $1 \mathrm{~kb}=$ DNA ladder (bp) : 250, 500, 750, 1500, 2000, 2500, 3000, 4000, 5000, 6000, 8000, 10000. CS1-CS4 = stripped snakehead; CP1-CP4 = ocellated snakehead

The BLASTn analysis showed that COI sequences in this study conceded with those in the GenBank database. $C$. striata from Kelekar and Danau Burung Besar River, South Sumatra had the highest percentage of identity (100\%) to the same species from Java and Bali, Indonesia (Accession code KU692420), but showed lower percentage of identity $(97 \%)$ to the same species from India (Accession code MG675617 and KJ936901). Table 2 indicated that $C$. pleurophthalma had $100 \%$ identity to the same species from Musi Banyuasin (Accession code KM213041) and Banjarmasin (KJ937345) but denoted lower identity (8783\%) to C. diplogramme, C. micropeltes, C. gachua, and C. limbata.

Irmawati et al. (2017) reported COI gene nucleotides of snakehead fish from Towuti Lake, Sorowako in South Sulawesi indicated 99\% homology with Channa striata from Cigede, Tasikmalaya, West Java (Accession code KU692418), and Rawa Pening Lake, Ambarawa, Central Java (KU692421). Wallace (1876) in Woodruff (2010) divided Asia into the Indochinese, Sundaic, and Philipines zoogeographic subregions, meanwhile the Wallacean, lies to the east, has more similar to Australian biota. This study showed that either $C$. striata or $C$. pleurophthalma was concordance to Wallace statement where the diverse communities within each subregion in Asia share a common biogeographic history and many genera and families of plants and animals.

Genetic distance at this study was also used to determine the genetic relationship between $C$. striata and C. pleurophthalma (Table 3). The value of genetic distance within C. striata based on the COI gene ranged from 0.002 to 0.100 , however, all C. pleurophthalma samples were identical. The two species had a genetic distance ranged from 0.110 to 0.116 . This distance was very small, because the value did not reach 1 , which means the kinship was very close. However, the data denoted that within the species barcode variation was low compared to the 
sequence variation between $C$. striata and $C$. pleurophthalma. This phenomenon can be said as a monophyletic kinship which means a group of taxa originating from the same ancestor. Various studies also proved that the genetic distance within the genus is lower than between the genus (Avise et al. 1987; Hebert et al. 2003; Khan et al. 2010). The results of genetic distance analysis will affect the reconstruction of phylogenetic trees.

\section{Phylogenetics}

The phylogenetic tree showed that $C$. striata and $C$. pleurophthalma were clustered in separate clades with a scale of 0.02 (Figure 2). As prediction, fishes from the same species were clustered closely into a single clade.

The phylogenetic tree indicated 2 different clades (monophyletic groups) i.e C. striata and C. pleurophthalma with $O$. niloticus as an outgroup species (Fig. 2). The first clade showed two different clusters, where $C$. striata from India were separated to the same species from Vietnam, China, the Philippines, Brunei Darussalam, Thailand, Malaysia, Indonesia (West and Central Kalimantan), USA and Indonesia (PALI, Indralaya, Java, and Bali) (bootstrap value/bv $=100)$. However, those species also make a different sub-clusters within species, for instance, sample of this study were in different sub-clusters from Indonesia (West and Central Kalimantan), USA (bv=96) and also another sub-clusters of Vietnam, China, the Philippines, Brunei Darussalam, Thailand, and Malaysia (bv=89). Robert et al. (2018) reported there were two reciprocally monophyletic genomes of $C$. striata were identified along the west and east coast that may have been separated by mountain upthrusts throughout the central region of Sabah, Malaysia.

The second clade consisted of all C. pleurophthalma, $C$. diplogramma, C. micopeltes and a paraphyletic group of $C$. gachua (Vietnam and Laos) and C. limbata (Myanmar) (bv = 80). C. pleurophthalma from PALI and Indralaya were in the same cluster to the same species from Musi Banyuasin (KM213041) and Banjarmasin (KJ937345) (bv = 100), which are separated from $C$. diplogramma (India) and $C$. micropeltes (Indonesia and Malaysia) (bv = 81). The clade differences between $C$. striata and C. pleurophthalma are based on difference of nucleotide. There were 82 of nucleotide difference between species, but seven nucleotides caused a change in amino acids (Table 4). Five nucleotides were different within $C$. striata, however only one nucleotide at position 165 indicated an amino acid change, however, there was no difference in the nucleotide within species of C. pleurophthalma.

Table 1. The top hit match in the GenBank database of COI nucleotide of striped snakehead (C. striata)

\begin{tabular}{lcll}
\hline \multicolumn{1}{c}{ Species } & $\begin{array}{c}\text { Identity } \\
(\mathbf{\%})\end{array}$ & \multicolumn{1}{c}{ Accession no. } & \multicolumn{1}{c}{ Origin } \\
\hline Channa striata & $100 \%$ & KU692420 & Java and Bali, Indonesia \\
Channa striata & $99 \%$ & HM345931 & Aceh, Indonesia \\
Channa striata & $99 \%$ & MF496960 & Central Kalimantan, Indonesia \\
Channa striata & $99 \%$ & JQ661364 & Nakornsawan, Thailand \\
Channa striata & $99 \%$ & JF781203 & Kuala Lumpur, Malaysia \\
Channa striata & $98 \%$ & MF496954 & West Kalimantan, Indonesia \\
Channa striata & $98 \%$ & KT001935 & Can Tho, Vietnam \\
Channa striata & $98 \%$ & KC819606 & Shanghai, China \\
Channa striata & $98 \%$ & HQ654692 & Batangas, Filipina \\
Channa striata & $98 \%$ & MF496939 & Brunei Darusalam \\
Channa striata & $98 \%$ & KJ937425 & USA \\
Channa striata & $97 \%$ & MG675617 & Andhra Pradesh, India \\
Channa striata & $97 \%$ & KJ936901 & Tripura, India \\
\hline
\end{tabular}

Table 2. The top hit match in the GenBank database of COI nucleotide of ocellated snakehead (C.pleurophthalma)

\begin{tabular}{lccl}
\hline \multicolumn{1}{c}{ Species } & $\begin{array}{c}\text { Identity } \\
(\boldsymbol{\%})\end{array}$ & Accession no. & \\
\hline Channa pleuropthalma & $100 \%$ & KM213041 & Origin \\
Channa pleuropthalma & $100 \%$ & KJ937345 & Banjarmasin, Indonesia \\
Channa diplogramme & $87 \%$ & KJ937448 & Tamil Nadu, India \\
Channa diplogramme & $87 \%$ & KY750711 & Kerala, India \\
Channa micropeltes & $86 \%$ & KT001052 & Kuala Lumpur, Malaysia \\
Channa micropeltes & $86 \%$ & KM213040 & South Sumatra, Indonesia \\
Channa micropeltes & $85 \%$ & MF496862 & Perak, Malaysia \\
Channa gachua & $84 \%$ & MF496766 & Khammouan, Laos \\
Channa gachua & $84 \%$ & MF496738 & Dak Lak, Vietnam \\
Channa limbata & $83 \%$ & LC190116 & Shan State, Myanmar \\
\hline
\end{tabular}


Tabel 3. Genetic distance between striped snakehead (C. striata) and ocellated snakehead (C. pleurophthalma) based on COI gene

\section{No. Species}

Genetic Distance

\begin{tabular}{|c|c|c|c|c|c|c|c|c|c|c|c|c|c|c|c|c|c|c|c|c|c|c|c|c|c|c|c|}
\hline & & 1 & 2 & 3 & 4 & 5 & 6 & 7 & 8 & 9 & 10 & 11 & 12 & 13 & 14 & 15 & 16 & 17 & 18 & 19 & 20 & 21 & 22 & 23 & 24 & 25 & 26 \\
\hline 1 & C. striata_VNM_(Dak_Lak) & & & & & & & & & & & & & & & & & & & & & & & & & & \\
\hline 2 & C. striata_VNM_(Can_Tho) & 0.002 & & & & & & & & & & & & & & & & & & & & & & & & & \\
\hline 3 & C. striata_CHN_(Shanghai) & 0.003 & 0.003 & & & & & & & & & & & & & & & & & & & & & & & & \\
\hline 4 & C. striata_USA & 0.010 & 0.010 & 0.011 & & & & & & & & & & & & & & & & & & & & & & & \\
\hline 5 & C. striata_BRN & 0.001 & 0.001 & 0.002 & 0.009 & & & & & & & & & & & & & & & & & & & & & & \\
\hline 6 & C. striata_MLY_(Kuala_Lumpur) & 0.005 & 0.005 & 0.006 & 0.007 & 0.004 & & & & & & & & & & & & & & & & & & & & & \\
\hline 7 & C. striata_THA_(Phang_Nga) & 0.001 & 0.001 & 0.002 & 0.009 & 0.000 & 0.004 & & & & & & & & & & & & & & & & & & & & \\
\hline 8 & C. striata_THA_(Nakornsawan) & 0.003 & 0.003 & 0.004 & 0.007 & 0.002 & 0.002 & 0.002 & & & & & & & & & & & & & & & & & & & \\
\hline 9 & C. striata_PHL_(Nueva_Ecija) & 0.001 & 0.001 & 0.002 & 0.009 & 0.000 & 0.004 & 0.000 & 0.002 & & & & & & & & & & & & & & & & & & \\
\hline 10 & C. striata_PHL_(Laguna) & 0.001 & 0.001 & 0.002 & 0.009 & 0.000 & 0.004 & 0.000 & 0.002 & 0.000 & & & & & & & & & & & & & & & & & \\
\hline 11 & C. striata_PHL_(Batangas) & 0.004 & 0.004 & 0.005 & 0.012 & 0.003 & 0.006 & 0.003 & 0.005 & 0.003 & 0.003 & & & & & & & & & & & & & & & & \\
\hline 12 & C. striata_IND_(Tripura) & 0.018 & 0.018 & 0.017 & 0.017 & 0.017 & 0.015 & 0.017 & 0.015 & 0.017 & 0.017 & 0.020 & & & & & & & & & & & & & & & \\
\hline 13 & C. striata_IND_(Andhra_Pradesh) & 0.019 & 0.019 & 0.018 & 0.018 & 0.018 & 0.016 & 0.018 & 0.016 & 0.018 & 0.018 & 0.021 & 0.005 & & & & & & & & & & & & & & \\
\hline 14 & C. striata_IDN_(PALI1') & 0.009 & 0.009 & 0.010 & 0.010 & 0.008 & 0.006 & 0.008 & 0.006 & 0.008 & 0.008 & 0.011 & 0.018 & 0.017 & & & & & & & & & & & & & \\
\hline 15 & C. striata_IDN_(PALI2') & 0.009 & 0.009 & 0.010 & 0.010 & 0.008 & 0.006 & 0.008 & 0.006 & 0.008 & 0.008 & 0.011 & 0.018 & 0.017 & 0.000 & & & & & & & & & & & & \\
\hline 16 & C. striata_IDN_(Central_Kalimantan) & 0.007 & 0.007 & 0.008 & 0.003 & 0.006 & 0.005 & 0.006 & 0.005 & 0.006 & 0.006 & 0.009 & 0.014 & 0.015 & 0.007 & 0.007 & & & & & & & & & & & \\
\hline 17 & C. striata_IDN_(West_Kalimantan) & 0.010 & 0.010 & 0.011 & 0.000 & 0.009 & 0.007 & 0.009 & 0.007 & 0.009 & 0.009 & 0.012 & 0.017 & 0.018 & 0.010 & 0.010 & 0.003 & & & & & & & & & & \\
\hline 18 & C. striata_IDN_(Aceh) & 0.005 & 0.005 & 0.006 & 0.009 & 0.004 & 0.002 & 0.004 & 0.002 & 0.004 & 0.004 & 0.006 & 0.017 & 0.018 & 0.006 & 0.006 & 0.006 & 0.009 & & & & & & & & & \\
\hline 19 & C. striata_IDN_(Java_Bali) & 0.009 & 0.009 & 0.010 & 0.010 & 0.008 & 0.006 & 0.008 & 0.006 & 0.008 & 0.008 & 0.011 & 0.018 & 0.017 & 0.000 & 0.000 & 0.007 & 0.010 & 0.006 & & & & & & & & \\
\hline 20 & C. striata_IDN_(Indralaya 1') & 0.010 & 0.010 & 0.011 & 0.011 & 0.009 & 0.007 & 0.009 & 0.007 & 0.009 & 0.009 & 0.012 & 0.019 & 0.018 & 0.001 & 0.001 & 0.008 & 0.011 & 0.007 & 0.001 & & & & & & & \\
\hline 21 & C. striata_IDN_(Indralaya2') & 0.010 & 0.010 & 0.011 & 0.011 & 0.009 & 0.007 & 0.009 & 0.007 & 0.009 & 0.009 & 0.012 & 0.019 & 0.018 & 0.001 & 0.001 & 0.008 & 0.011 & 0.007 & 0.001 & 0.000 & & & & & & \\
\hline 22 & C.pleurophthalma_IDN_(South_Sumatra) & 0.112 & 0.115 & 0.114 & 0.110 & 0.114 & 0.108 & 0.114 & 0.111 & 0.114 & 0.114 & 0.116 & 0.113 & 0.113 & 0.113 & 0.113 & 0.110 & 0.110 & 0.111 & 0.113 & 0.114 & 0.114 & & & & & \\
\hline 23 & C. pleuropthalma_IDN_(PALI 1') & 0.112 & 0.115 & 0.114 & 0.110 & 0.114 & 0.108 & 0.114 & 0.111 & 0.114 & 0.114 & 0.116 & 0.113 & 0.113 & 0.113 & 0.113 & 0.110 & 0.110 & 0.111 & 0.114 & 0.114 & 0.114 & 0.000 & & & & \\
\hline 24 & C. pleuropthalma_IDN_(PALI2') & 0.112 & 0.115 & 0.114 & 0.110 & 0.114 & 0.108 & 0.114 & 0.111 & 0.114 & 0.114 & 0.116 & 0.113 & 0.113 & 0.113 & 0.113 & 0.110 & 0.110 & 0.111 & 0.115 & 0.114 & 0.114 & 0.000 & 0.000 & & & \\
\hline 25 & C.pleuropthalma_IDN_(1ndralaya1*) & 0.112 & 0.115 & 0.114 & 0.110 & 0.114 & 0.108 & 0.114 & 0.111 & 0.114 & 0.114 & 0.116 & 0.113 & 0.113 & 0.113 & 0.113 & 0.110 & 0.110 & 0.111 & 0.116 & 0.114 & 0.114 & 0.000 & 0.000 & 0.000 & & \\
\hline 26 & C. pleuropthalma_IDN_(1ndralaya2*) & 0.112 & 0.115 & 0.114 & 0.110 & 0.114 & 0.108 & 0.114 & 0.111 & 0.114 & 0.114 & 0.116 & 0.113 & 0.113 & 0.113 & 0.113 & 0.110 & 0.110 & 0.111 & 0.117 & 0.114 & 0.114 & 0.000 & 0.000 & 0.000 & 0.000 & \\
\hline 27 & C. pleurophthalma_ION_(Banjarmasin) & 0.112 & 0.115 & 0.114 & 0.110 & 0.114 & 0.108 & 0.114 & 0.111 & 0.114 & 0.114 & 0.116 & 0.113 & 0.113 & 0.113 & 0.113 & 0.110 & 0.110 & 0.111 & 0.118 & 0.114 & 0.114 & 0.000 & 0.000 & 0.000 & 0.000 & 0.000 \\
\hline
\end{tabular}


According to Avise (1994), the use of mitochondrial DNA sequences can clarify the relationship between species in evolution that was blurred due to morphological variations. Furthermore, Zhu et al. (2013) stated that identification of this species based on morphological characters showed very erratic results because of the high diversity of $C$. striata. Song et al. (2013) observed that genetic diversity within Channa striata was lower than that of other species and did not correlate to morphological variations. Phylogenetic relationships illustrated the possibility of genetic mixing among populations (Laudien et al. 2003), caused by several factors such as genetic flow (gene flow) and introduced activities by humans. C. striata are very widely distributed in Asia from Pakistan, India and Sri Lanka, all parts of the country of Myanmar, Thailand, Cambodia, Vietnam, Malaysia and Indonesia (Grand et al. 2017). The mainland of Peninsular Malaysia, the islands of Borneo, Thailand, Indo-China, and Sumatra were once part around 250,000 years ago. Because of the effects of maximum seawater declining, the mainland of Peninsular Malaysia and the island of Borneo were once connected by lowlands traversed by rivers, which was rich in diversity of fish because fish flowed out the east coast of Peninsular Malaysia, the west coast of Kalimantan and Sumatra. This condition allows the migration of species $C$. striata between regions (Benziger et al. 2011).



Figure 2. Phylogenetic tree of striped snakehead (C. striata) and ocellated snakehead (C. pleurophthalma) was constructed using Neighbor-Joining (NJ) method. *): specimen of current study. C. striata : Indonesia (KU692420, HM345931, MF496960, MF496954), Thailand (JQ661364), Malaysia (JF781203), Vietnam (KT001935), China (KC819606), Filipina (HQ654692), Brunei (MF496939), USA (KJ937425) and India (MG675617, KJ936901). C. pleurophthalma (Indonesia: KM213041, KJ937345), C. diplogramme (India: KJ937448, KY750711), C. micropeltes (Malaysia : KT001052, MF496862; Indonesia: KM213040), C. gachua (Vietnam: MF496766, MF496738), C. limbata (Myanmar: LC190116). 
Table 4. Polymorphic site of nucleotide and amino acids in COI gene between C. striata and C. pleurophthalma

\begin{tabular}{cclll}
\hline No & Nucleotide & Position & Amino acid & Origin of species \\
\hline \multicolumn{2}{l}{ Channa striata } & & & \\
1 & T & 57 & no change & Kelekar River and Pali (current study), Java and Bali, Andrha_Pradesh \\
& C & 57 & no change & Others sample \\
2 & C & 60 & no change & Kelekar River and Pali (current study), Java and Bali, Andrha_Pradesh \\
& T & 60 & no change & Others sample \\
3 & A & 165 & I & Kelekar River and Pali (current study), Java and Bali, Andrha_Pradesh \\
& G & 165 & M & Others sample \\
4 & T & 342 & no change & Kelekar River and Pali (current study), Java and Bali, Andrha_Pradesh \\
& A & 342 & no change & Others sample \\
5 & C & 429 & no change & Kelekar River and Pali (current study) others sample \\
& T & & no change & Others sample
\end{tabular}

Channa pleurophthalma

There was no difference of nucleotide and amino acids within species in this study and GenBank database

\begin{tabular}{|c|c|c|c|c|}
\hline \multicolumn{5}{|c|}{ Channa striata vs $C$. pleurophthalma* } \\
\hline \multirow[t]{2}{*}{1} & A & 120 & I & C. pleurophthalma \\
\hline & G & & M & C. striata \\
\hline \multirow[t]{2}{*}{2} & G & 129 & M & C. pleurophthalma \\
\hline & A & & I & C. striata \\
\hline \multirow[t]{2}{*}{3} & G & 150 & $\mathrm{~W}$ & C. pleurophthalma \\
\hline & A & & Deletion & C. striata \\
\hline \multirow[t]{2}{*}{4} & A & 183 & I & C. pleurophthalma \\
\hline & G & & $\mathrm{M}$ & C. striata \\
\hline \multirow[t]{2}{*}{5} & G & 216 & W & C. pleurophthalma \\
\hline & A & & Deletion & C. striata \\
\hline \multirow[t]{2}{*}{6} & G & 420 & M & C. pleurophthalma \\
\hline & A & & I & C. striata \\
\hline \multirow[t]{2}{*}{7} & A & 465 & Deletion & C. pleurophthalma \\
\hline & G & & $\mathrm{W}$ & C. striata \\
\hline
\end{tabular}

Note: There were 82 different nucleotides between C. striata and C. pleurophthalma, however only 7 were different in amino acids.

Table 5. Water qualities of Kelekar and Danau Burung Besar River

\begin{tabular}{lcc}
\hline \multirow{2}{*}{ Parameter } & \multicolumn{2}{c}{ River } \\
\cline { 2 - 3 } & Kelekar & $\begin{array}{c}\text { Danau } \\
\text { Burung Besar }\end{array}$ \\
\hline Temperature $\left({ }^{\circ} \mathrm{C}\right)$ & $31-31.6$ & $29.3-30.7$ \\
pH (Unit) & $4.76-4.96$ & $4.6-6.7$ \\
DO (mg. $\left.\mathrm{L}^{-1}\right)$ & $2.7-3.0$ & $1.31-3.76$ \\
Ammonia $\left(\mathrm{mg} . \mathrm{L}^{-1}\right)$ & $<0.009$ & $0.17-0.20$ \\
Alkalinity $\left(\mathrm{mg} \cdot \mathrm{L}^{-1} \mathrm{CaCO}_{3}\right)$ & 20 & 30 \\
Turbidity $(\mathrm{cm})$ & $62.5-63$ & $50-90$ \\
\hline
\end{tabular}

\section{Water quality}

The water qualities during fish collection were presented in Table 5. Based on measurements in both of river, the temperature in Kelekar $\left(31-31.6^{\circ} \mathrm{C}\right)$ and Danau Burung Besar $\left(29.3-30.7^{\circ} \mathrm{C}\right)$ were still in good condition for the life of striped snakehead and ocellated snakehead. Striped snakehead can live with water temperature ranging between $26.5-31.5^{\circ} \mathrm{C}$ (Syafei et al. 1995), while ocellated snakehead can live at a temperature of $27-30^{\circ} \mathrm{C}$ (Said, 2007). The $\mathrm{pH}$ value of the rivers ranged between 4.76-6.7. This condition was still supported for growth and survival of two species. These fish are able to live and grow at a fairly wide $\mathrm{pH}$ susceptibility, which ranges from 4-7 for striped snakehead (Balai Perikanan Budidaya Air Tawar Mandiangin, 2014) and 5-6.5 for ocellated snakehead (Said, 2007).

According to Muslim (2017), striped snakehead was mostly found in swamps, living in shallow waters. Dissolved oxygen levels in the Kelekar River ranged from 2.7 to $3.0 \mathrm{mg} . \mathrm{L}^{-1}$, while in the Danau Burung Besar River was 1.31-3.76 mg. $\mathrm{L}^{-1}$. This parameter was less appropriate, however, striped snakehead has an additional breathing device, diverticula to support fish life (Kottelat et al. 1993). Tropical fish species can grow well in dissolved oxygen content $>5 \mathrm{mg} . \mathrm{L}^{-1}$, with lethal concentrations $<0.3 \mathrm{mg}$. $\mathrm{L}^{-1}$ (Zweig et al. 1999). Ammonia value in the Kelekar and Danau Burung Besar River was <0.009 and 0.17-0.20 mg. $L^{-1}$, respectively. Effendi (2003) stated that a maximum of ammonia level to support fish life is no more than 0.2 mg.L ${ }^{-1}$. These also suit for striped snakehead (Balai Perikanan Budidaya Air Tawar Mandiangin, 2014). The alkalinity was $20 \mathrm{mg} . \mathrm{L}^{-1}$ in the Kelekar River and $30 \mathrm{mg} . \mathrm{L}^{-}$ ${ }^{1}$ in the Danau Burung Besar River. These values were still in optimum conditions for striped snakehead and ocellated snakehead. Total alkalinity in natural freshwater systems ranges from 5 to $500 \mathrm{mg}$. $\mathrm{L}^{-1}$ (Lawson 1995). The turbidity value of the Kelekar River ranged from 62.5 to $63 \mathrm{~cm}$, while at Danau Brurung Besar was $50-90 \mathrm{~cm}$. This 
turbidity level was still in tolerance for the life of striped snakehead and ocellated snakehead. According to Ageriyanto (2012), striped snakehead can still be found and grown well in waters with values ranging from $65-145 \mathrm{~cm}$. In general, the productivity of aquatic organisms increases at turbidity level between 30-65 cm (Boyd dan Licthkoppler 1979).

In conclusion, $C$. striata and $C$. pleurophthalma from Indralaya, and PALI, South Sumatra have been successfully barcoded, where the two species were clustered in separate branches. Water quality of Kelekar River indicated that temperature was $31-31.6^{\circ} \mathrm{C}$, turbidity (62.5-63 cm), $\mathrm{pH}$ (4.76-4.79), dissolved oxygen (2.7-3.0 $\mathrm{mg} / \mathrm{L})$, ammonia $(<0,009 \mathrm{mg} / \mathrm{L})$, and alkalinity total was 20 $\mathrm{mg} / \mathrm{L}$, were still in tolerance for both species.

\section{ACKNOWLEDGEMENTS}

We thank staff at Aquaculture Laboratory and Plant Physiology Laboratory, Faculty of Agriculture, Sriwijaya University, Indonesia. The authors also acknowledge the contribution of the Sriwijaya University for Competitive Research Grant (No. 0007/UN9/SK.LP2M.PT/2018).

\section{REFERENCES}

Ageriyanto. 2012. Studi sumberdaya ikan dan implikasinya bagi pengelolaan perikanan di Situ IPB, kampus IPB Dramaga, Bogor. [Hon. Thesis]. Institut Pertanian Bogor, Bogor. [Indonesian]

Avise JC. 1994. Molecular markers, naturally history and evolution. Chapman and Hall, New York.

Balai Perikanan Budidaya Air Tawar Mandiangin. 2014. Naskah akademik ikan gabus haruan (Channa striata Bloch, 1793) hasi domestikasi. Direktorat Jenderal Perikanan Budidaya, Mandiangin. [Indonesian]

Benziger A, Phili S, Raghavan R, Anvar APH, Sukumaran M, Tharian JC, Dahanukar N, Baby F, Peter R, Devi KR, Radhakrishan KV, Hanifa MA, Britz R. 2011. Unravelling a 146 years old taxonomic puzzle: validation of Malabar snakehead, species-status and its relevance for channid systematic and evolution. Plos One 6 (6): e21272. DOI: 10.1371/journal.pone.0021272.

Boyd CE, Lichtkoppler F. 1979. Water Quality Management in Fish Ponds. Research and Development Series No. 22, International Centre for Aquaculture (J.C.A.A) Experimental Station Auburn University, Alabama.

Brown W, George M, Wilson A. 1979. Rapid evolution of animal mitochondrial DNA. Proc Natl Acad Sci USA, 76 (4): 1967-1971.

Courtenay JrWR, Williams JD. 2004. Snakeheads (Pisces, Channidae). A Biological Synopsis and Risk Assessment. U.S. Geological Survey Circular 1251. U.S. Geological Survey, Reston, VA.

D'Amato ME, Esterhuyse MM, Waal BCW, Brink D, Volckaert FAM 2007. Hybridization and phylogeography of the Mozambique tilapia Oreochromis mossambicus in Southern Africa evidenced by mitochondrial and microsatellite DNA genotyping. Conserv Genet 8 (2): 475-488

Froese R, Pauly D. 2018. Fishbase. World Wide Web electronic publication. www.fishbase.org version (11/2018).

Grand CC, Brizt R, Dahanukar N, Rajeev R, Pethiyagoda R, Tan HH, Hadiaty RK, Norsham SY, Riber L. 2017. Barcoding snakeheads (Teleostei, Channidae) revisited: discovering greater species diversity and resolving perpetuated taxonomic confusion. Plos One 12 (9): e0184017. DOI: 10.1371/journal.pone.0184017.

Hebert PDN, Ratnasingham S, Waard DJR. 2003. Barcoding animal life: Cytochrome c oxidase subunit 1 divergence among closely related species. Proc R Soc 270: 96-99.
Irmawati, Tresnati J, Nadiarti, Fachruddin L, Arma NR, Haerul A. 2017. Identification of wild stock and the first generation (F1) of domesticated snakehead fish, Channa spp. (Scopoli 1777) using partial Cytochrome C Oxidase Subunit I (COI) gene. Jurnal Indonesia Iktiologi 17 (2): 165-173.

Khan SA, Lyla PS, John BA, Kuamr CP, Murugan S, Jalal KCA. 2010. DNA Barcoding of Stolephorus indicus, Stolephorus commersonnii and Terapon jarbua of Parangipettai Coastal Waters. Biotechnology. 9: 373-377.

Kimura M. 1980. A simple method for estimating evolutionary rate of base substitutions through comparative studies of nucleotide sequences. J Mol Evol 15: 111-120.

Kotellat AAJ, Whitten SN Kartikasari, Wiryoatmodjo A. 1993. Fresh Water Fishes of Western Indonesia and Sulawesi. Periplus edition, Jakarta.

Kumar S, Stecher G, Tamura K. 2016. MEGA7: Molecular Evolutionary Genetics Analysis Version 7.0 for Bigger Datasets. Mol Biol Evol 33: 1870-1874.

Laudien J, Flint NS, Van DBFH, Brey T. 2003. Genetic and morphological variation in four populations of the surf clam donax serra (Roding) from Southern African Sandy Beach. Biochem Syst Ecol 31 (7): 751-772.

Lawson TB. 1995. Fundamentals of Aquacultural Engineering. Chapman and Hall, New York.

Muslim, 2017. Budidaya Ikan Gabus (Channa striata). Unsri Press, Indralaya. [Indonesian]

Muslim. 2013. Jenis-jenis ikan gabus (genus Channa) di perairan rawa banjiran sungai Kelekar Indralaya Ogan Ilir Sumatra Selatan. Prosiding Seminar Nasional Biologi Untuk Kesejahteraan Manusia dan Lingkungan.

Nagl S, Tichy H, Mayer WE, Samonte IE, McAndrew, BJ, Klein J. 2001. Classification and phylogenetic relationships of African tilapiine fishes inferred from mitochondrial DNA sequences. Mol Phylogenet Evol 20 (3): 361-374

Peloa A, Wullur S, Sinjal CA, 2015. Amplifikasi gen Cytochrome Oxidase Subunit I (COI) dari sampel sirip ikan hiu dengan menggunakan beberapa pasangan primer. Jurnal Pesisir dan Laut Tropis (1): 38. [Indonesian]

Pratama MRN, Syaifudin M, Muslim M. 2017. DNA barcode application of striped catfish (Pangasius hypopthalmus) and Asian Catfish (Pangasius macronema) based on cytochrome c oxidase subunit I (COI). Proceeding of National Seminar in Suboptimal Area. Universitas Sriwijaya, Palembang.

Rajiv K, Chauhan T. 2010. Molecular markers and their applications in fisheries and aquaculture. Adv Biosci Biotechnol 1 (4): 281-291. DOI: 10.4236/abb.2010.14037.

Robert R, Amit NH, Sukarno NM, Majapun RJ, Kumar SV. 2018. Population genetic structure of Asian snakehead fish (Channa striata) in North Borneo: Implication conservations of local freshwater biodiversity. Ecol Res 34 (1): 55-67.

Rognon X, Guyomard R. 1997. Mitochondrial DNA differentiation among East and West African Nile tilapia populations. J Fish Biol 51 (1): 204-207.

Said A. 2007. Biological aspects of serandang (Channa pleuropthalma) in Musi catchment area, South Sumatra. Research Institute for Inland Fisheries and Extension, Palembang.

Song LM, Munian K, Rashid AZ, Bhassu S. 2013. Characterisation of Asian snakehead Murrel Channa striata (Channidae) in Malaysia: An insight into molecular data and morphological approach. Sci World J 2013: 917506. DOI: 10.1155/2013/917506

Syafei DS, Malik BBA, Suherman HA. 1995. Introduction of various fishes from inland fisheries. Report of Fisheries Department, Jambi Province, Indonesia.

Syaifudin M, Bekaert B, Taggart JB, Bartie KL, Wehner S, Palaiokostas C, Khan MGQ, Selly SLC, Hulata G, D'Cotta H, Baroiller JF, McAndrew BJ, Penman DJ. 2019. Species-specific Marker Discovery in Tilapia. Sci Rep 9: 13001. DOI: 10.1038/s41598-019-48339-2.

Syaifudin M, Dade J, Muslim, Ayu D. 2017. DNA authentication of Asian redtail catfish Hemibragus nemurus from Musi and Penukal River, South Sumatra Indonesia. Genetic of Aquatic Organism 1: 43-48.

Syaifudin M, Jubaedah D, Yonarta D, Hastuti Z. 2019. DNA barcoding of snakeskin gourami Trichogaster pectoralis and blue gourami Trichogaster trichopterus based on cytochrome c oxidase subunit I (COI) gene. IOP Conf. Ser: Earth Environ Sci 348: 01203. DOI: 10.1088/1755-1315/348/1/012031. 
Ward RD, Zemlak TS, Ines BH, Last PR, Hebert PDN, 2005. DNA barcoding Australia's fish species. Phil Trans R Soc B 360: 1847 1857.

Woodruff DS. 2010. Biogeography and conservation in Southeast Asia: How 2.7 million years of repeated environmental fluctuations affect today's patterns and the future of the remaining refugial-phase biodiversity. Biodiv Conserv 19: 919-941.
Zhu SR, Ma KY, Xing ZJ, Xie N, Wang YX, Wang Q, Li JL. 2013. The complete mitochondrial genome of Channa argus, Channa maculata and hybrid snakehead fish [Channa maculata (ㅇ) x Channa argus (ふ)]. Mitochondrial DNA 24 (3): 217-218.

Zweig RD, Morton JD, Stewart MM. 1999. Source Water Quality for Aquaculture: A Guide for Assessment. The World Bank, Washington, D.C., USA. 